\title{
Inhibition of Interaction between CagA and Shp-2 Domain by Using Medicinal Plant Products
}

\section{Zoltan Szomor*}

Hurstville Knee Clinic, Suite 406, 12-14 Ormonde Parade, Hurstville 2220, Sydney, Australia

\begin{abstract}
Aim: Inhibition of CagA tyrosine phosphorylation or disruption of the CagA-SHP-2 complex, to prevent the bacteria function which may leads to the peptic ulcers and gastric Adeno carcinoma, by using medicinal plants.

The CagA-SHP-2 interaction is dependent on CagA tyrosine phosphorylation and, through the complex formation. SHP2 plays a pivotal role in growth factor and cytokine signaling.

By inhibiting this CagA-SHP-2 domain complex, we can prevent the survival of the bacteria in the host.

This inhibition of CagA-SHP-2 complex can be done by using various chemical compounds like NSC87877, Salicylic acid etc. These compounds have the ability to inhibit the CagA-SHP-2 domain. The functional compounds of these compounds can inhibit the CagA-SHP-2.

In our study here we targeting the CagA-SHP2 complex inhibition by using some medicinal plants like quinoline compounds, black tea, turmeric, nutmeg, ginger [1]. Previous studies proven that, these medicinal plants products have the bactericidal effect on $H$. pylori culture, that these plants have nearly $95-100 \%$ of $H$. Pylori growth inhibition, it predict that these plant products can be inhibit the growth the $\mathrm{H}$. Pylori culture, so here we focusing on that these plants can able to inhibit the CagA-SHP-2 domain complex.
\end{abstract}

Keywords: CagA; SHP-2; CagA-SHP-2 domain complex

\section{Introduction}

Helicobacter pylori, a spiral-shaped bacterium that colonizes the human gastric mucosa, is estimated to inhabit at least half of the world's human population. Since its first report in 1984 by Marshall and Warren, $H$. pylori has been recognized as the etiological agent of gastric diseases such as chronic atrophic gastritis and peptic ulcers, with each strain showing differences in their genome sequence by more than $20 \%$ [2]. Epidemiological studies have revealed the importance of several genetic elements, such as $\operatorname{CagA}$ pathogenicity island (PAI), in the development of gastro duodenal disorders.

H. pylori also play a critical role in the development of both intestinal and diffuse types of gastric adenocarcinoma [3-5].

A number of genes, including $\operatorname{CagA}$, VacA, BabA, and IceA, have been implicated in enhancement of virulence of $H$. pylori bacteria.

Helicobacterpylori strains producea 120-145 kDaimmunodominant protein called Ctotoxin associated gene A (CagA) antigen. The CagA gene that encodes CagA protein by a process of horizontal transfer, through the type IV secretion system, through which macromolecules are delivered into the host.

SHP-2, a cellular target of tyrosine phosphorylated CagA. Upon tyrosine phosphorylation by SFK, CagA acquires the ability to bind specifically to SHP-2, the injected CagA binds and deregulates SHP-2 and other intracellular signaling molecules in both tyrosine phosphorylation-dependent and -independent manners, generating deregulated signals for cell growth and cell movement CagA also disrupts the cell-cell junctions, destroying normal epithelial architecture.

\section{Rationale of The Proposal}

Helico bacter pylori induce gastric inflammations in virtually all colonized individuals and such gastritis increase the risk for peptic ulcer diseases and distal gastric adenocarcinoma [6-8].

The Src homology -2 domain containing protein tyrosine phosphatase-2 (SHP-2) plays a pivotal role in growth factor and cytokine signaling.

In this studies our aim and objective is to inhibit the complex formation of Cag A-SHP-2, which plays a major responsible in the peptic ulcers and gastric adenocarcinomas, by using medicinal plants, which already used in the inhibition of the growth of helicon bacter cultures.

\section{Methodology}

Here our main target is on the CagA-SHP-2 domain complex. For the inhibition of this complex we perform the following tests.

\section{Cell culture, immunoprecipitation and immunoblotting}

Cell culture will be treated with the plant products as described in Chen L et al. [9].

In this tests the cell culture will be treated with plant compounds as described in Chen L et al. 2001 Erk1/2 kinase assay will be done as described in Cunnick et al. [10].

*Corresponding author: Zoltan Szomor, Hurstville Knee Clinic, Suite 406, 12-14 Ormonde Parade, Hurstville 2220, Sydney, Australia, E-mail: zoltanszomor@gmail.com

Received June 29, 2012; Accepted October 27, 2012; Published October 29 2012

Citation: Szomor Z (2012) Inhibition of Interaction between Caga and Shp-2 Domain by Using Medicinal Plant Products. Adv Pharmacoepidem Drug Safety 1:121. doi:10.4172/2167-1052.1000121

Copyright: ( $) 2012$ Szomor Z. This is an open-access article distributed under the terms of the Creative Commons Attribution License, which permits unrestricted use, distribution, and reproduction in any medium, provided the original author and source are credited. 
Citation: Szomor Z (2012) Inhibition of Interaction between Caga and Shp-2 Domain by Using Medicinal Plant Products. Adv Pharmacoepidem Drug Safety 1:121. doi:10.4172/2167-1052.1000121

Page 2 of 2

\section{Immune complex PTP (Protein tyrosine phosphatase) assay}

Cell culture is treated with plant compounds and EGF as described in Chen L et al. 2001.

Immunoprecipitation complex signal is measured by DiFMUP (6,8-difluoro-4-methylumbelliferyl phosphate) [a fluorescent dye].

The culture growth in Cell culture assay can be observed with the comparison of control and test.

In test wells there is a presence of all compounds like cells, inhibitor (plant compounds), and growth factors of like EGF were to be added, whereas in control wells everything were to be added except the inhibitor.

\section{Cytotoxicity or cell viability assay}

Here viable cells can be identified with the help of fluorescent dyes here also we use both controls and tests. It resemble with MTT assay.

In control wells there is no inhibitor and in the test wells there is an inhibitor.

\section{Discussion}

1. It is proved that $H$. pylori growth can be inhibited by using medicinal plants.

2. The Cag A-SHP-2 domain complex can be inhibited with the chemicals like NSC87877, salicylic acid, etc.

Based on these criteria, here we aimed to inhibit CagA-SHP-2 complex by using medicinal plants.

\section{Conclusion}

By performing these studies, with the help of medicinal plant products to inhibit the CagA-SHP2 domain complex, there will be a less chance for occurrence of side effects and it will be low in costs also.

\section{References}

1. Mahady GB, Pendland SL, Yun GS, Lu ZZ, Stoia A (2003) Ginger (Zingiber oficinale Roscoe) and the gingerols growth of Cag $A+$ strains of Helicobacter pylori. Anticancer Res 23: 3699-3702.

2. Salama N, Guillemin K, McDaniel TK, Sherlock G, Tompkins L, et al. (2000) A whole-genome microarray reveals genetic diversity among Helicobacter pylori strains. Proc Natl Acad Sci USA 97: 14668-14673.

3. Forman D, Newell DG, Fullerton F, Yarnell JW, Stacey AR, et al. (1991) Association between infection with Helicobacter pylori and risk of gastric cancer: evidence form a prospective investigation. Br Med J 302: 1302-1305.

4. Parsonnet J, Friedman GD, Vandersteen DP, Chang Y, Vogelman JH, et al. (1991) Helicobacter pylori infection and the risk of gastric carcinoma. N Engl J Med 325: 1127-1131.

5. Nomura A, Stemmermann GN, Chyou PH, Kato I, Perez-Perez GI, et al (1991) Helicobacter pylori infection and gastric carcinoma among Japanese Americans in Hawaii. N Engl J Med 325: 1132-1136.

6. Correa P (1996) Helicobacter pylori and gastric cancer: state of the art. Cancer Epidemiol Biomarkers Prev 5: 477-481.

7. Dooley CP, Cohen H, Fitzigibbons PL, Bauer M, Appleman MD, et al. (1989) Prevalence of Helicobacter pylori infecyions and histologic gastrirtis in assymptomatic persons. N ENgl J Med 321: 1562-1566.

8. Dunn BE, Cohen H, Blaser MJ (1997) Helicobacter pylori. Clin Microbiol Rev 10: $720-741$.

9. Chen L, Sung SS, Yip ML, Lawrence HR, Ren Y, et al. (2006) Discovery of a Novel Shp2 Protein Tyrosine Phosphatase Inhibitor. Mol Pharmacol 70: 562570

10. Cunnick JM, Dorsey JF, Mei L, Wu J (1998) Reversible regulation of SHP-1 tyrosine phosphatase activity by oxidation. Biochem Mol Biol Int 45: 887-894. 